\title{
保存的頸部郭清後の内頸静脈開存について
}

$$
\text { 今手祐 二 遠 藤 史 郎 大 上 研二 }
$$

\begin{abstract}
要旨 遊離皮弁の多用や術後の QOL 重視は近年保存的頸部郭清を増加させてきた。特に両頸部 郭清後の内頝静脈開存の有無は生命予後に影響する可能性があるため重要である。今回我々は保存 的頝部郭清（両側同時あるいは一側のみ）を行った 28 症例に対し術後 1 カ月以上経過した時点でエ コー検査を実施し，内頝静脈開存の有無を調べた。結果は閉塞例 1 例，狭窄例 2 例，内頝静脈開存 率は96\%であった。内頝静脈閉塞は術後の重篤な合併症が原因と考えられたが，狭窄例の原因や経 過について今後さらに検討する必要がある。

キーワード : 保存的頝部郭清, 内頝静脈開存, エコー
\end{abstract}

\section{Summary Internal jugular vein patency following functional neck dissection :}

Yuji lmate, Shiro Endo, Kenji Okami and Masahiro Takahashi Department of Otolaryngology Yamagushi University School of Medicine

Recently the incidence performance of functional neck dissection(FND) increased because of using of free graft and considering quality of life. The patency of internal jugular vein (IJV) after FND is important, because the possibility exists that bilateral jugular vein occlusion leads to serious postoperative morbidity.

The study group consisted of 28 patients who underwent a functional neck dissection at least on one side of the neck. The patency of IJV was examined by ultrasonogram 1 month to 5 years postoperatively. In one of them occlusion of the IJV was disclosed. In two patiets IJV was narrowed but patent. The preservation rate of patency of the IJV was $96 \%$ (27 of 28). The cause of IJV occlusion in our case was serious complications after operation. Further studies are needed to know the cause and the course of narrowed IJV.

Key words : Functional neck dissection, Patency of internal jugular vein, Ultrasonogram

\section{はじめに}

最近，頭頸部領域手術において，遊離皮弁の多 用や術後の QOL を考慮して, 保存的䅡部郭清 (FND) が行われる頻度が増加傾向にある。その 場合内頝静脈は保存されるが, 保存された内頝静

*山口大学医学部耳鼻咽喉科
脈は術後も開存すると一般的に了解されている。 我々は両頝部郭清後, FND 側の内頝静脈血栓症 を合併し両側の内頝静脈血流が遮断されたにも拘 わらず，自他覚的に症状を全く示さなかった症例 を経験した。一方, 両側の根治的頝部郭清 (RN D) 症例では死亡例1) や失明例2) が報告されてお り, FND 後の内䝺静脈の開存を確認することは 重要と考えられる。今回 FND 後の内頝静脈の 
開存の有無を調べ，閉塞例の原因を検討した。

\section{対象及び方法}

対象は1990年から1995年まで当科で行った一側 FND 4 例および一期的な両䅡部郭清 (一側 RND, 対側 FND) 24例の計28例である。

方法はエコー装置（アロカ, SSD-630, 7.5 $\mathrm{MHz}$ ，セクタスキャナ）を用いて内頝静脈開存 の有無を検查した。検査はいずれの症例も臥位で 行った。ドップラーにて内頝静脈血流が確認され， 術前検査所見に比較してその短径が $1 / 3$ 以下の場 合を狭窄と判定した。内頝静脈の所見は䅡部圧迫 により容易に変化するため，検查時頝部にはでき るだけ圧迫が加わらないように注意を払った。手 術から検查までの期間は 1 カ月から 5 年である。

\section{結果}

検查した28例中 1 例に内頝静脈の閉塞を（図 1)，2 例に狭窄を認めた（図 2)。25例では充分 な開存の所見が得られた（図 3 )。FND 後の内 頝静脈開存率は狭窄例を含め $96 \%$ であった。表 1 は原発部位, 原発部位およびリンパ節移転の TN 分類，再建皮弁，放射線治療，合併症，頝部郭清 について各症例のデータを示す。内頝静脈閉塞例 では，頝部膿瘍に対する手術時に血栓による完全 閉塞が確認された。術後のショック, 敗血症, 頝 部膿湯, 皮弁全壊死など非常に重篤な合併症が内 頝静脈閉塞の原因と考えられた。

\section{考察}

内頝静脈の開存を調べる検査方法としては, エ コー, CT, MRI, 血管造影などの画像診断法が ある。これまでの報告でも様々な方法が用いられ ている3-6)。CT, MRI の画像はエコーより優れ ているが，コストや血流確認の点で難がある。血 管造影は最も確実な方法であるが，コストや侵襲 の点からスクリーニング検査には適さない。これ らの理由から，今回の検查ではエコーを用いた。

RND は頭頸部悪性腫場の手術において高頻度 に行われる手術である。しかし両側内頝静脈の結 禁は脳浮腫など致死的な状況をもたらす可能性が ある。したがって，両側 RND が必要な場合は， 段階的に行われるのが一般的である ${ }^{3)}$ 。FD は 両側同時にあるいは RND と同時に併用されて おり，その理由は残存静脈が開存し続けると考え られているからである。FND 後の内頝静脈開存 に関する過去の報告を調べると，1988年のFisher らの報告以来 4 件の報告があり（表 2 ), 内頝静 脈の開存率は70〜94\%であった ${ }^{3-6)}$ 。我々の施設 における内頝静脈開存率は $96 \%$ で，これらの報告 と比較して高い值であった。

内頝静脈閉塞の原因について Leontsins ら ${ }^{3)}$ は，最も関係が深いのは手術手技であろうと述べ ている。手術手技以外の内頝静脈閉塞の原因とし て皮弁による圧迫や血管の損傷4-6)，感染や手術 ・癌による凝固系元進, 血圧低下など3)が考えら

表 1 症例臨床デー夕

\begin{tabular}{|c|c|c|c|c|c|c|c|}
\hline $\begin{array}{r}\text { 内頚静脈 } \\
\text { (症例数) }\end{array}$ & 原発部位 & T & $\mathrm{N}$ & 再建 & $\begin{array}{l}\text { 放射線治療 } \\
\text { (照射部位) }\end{array}$ & 合併症 & $\begin{array}{l}\text { 頚部郭清 } \\
\text { (症例数) }\end{array}$ \\
\hline 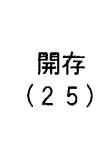 & $\begin{array}{c}\text { 口腔 } \\
\text { 咽頭 } \\
\text { 喉頭 } \\
\text { 外耳道 }\end{array}$ & $1 \sim 4$ & $0 \sim 2 \mathrm{c}$ & $\begin{array}{c}- \\
\text { 有茎 } \\
\text { 遊離 }\end{array}$ & $0 \sim 60$ Gy & $\begin{array}{c}\text { 胸水 } \\
\text { 咽頭瘦孔 } \\
\text { 頚部小膿痬 }\end{array}$ & 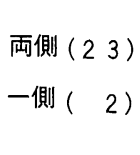 \\
\hline \multirow{2}{*}{$\begin{array}{l}\text { 狭窄 } \\
(2)\end{array}$} & 中咽頭 & 2 & 0 & 遊離 & 30 Gy（原発） & 小瘦孔 & 一側 \\
\hline & 舌·口腔底 & 3 & 1 & 遊離 & 30 Gy（原発・ & 䅡部）－ & 一側 \\
\hline $\begin{array}{c}\text { 閉塞 } \\
(1)\end{array}$ & 舌 - 口腔底 & 3 & $2 c$ & 有茎 & - & 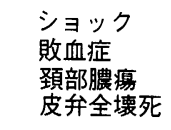 & 両側 \\
\hline
\end{tabular}




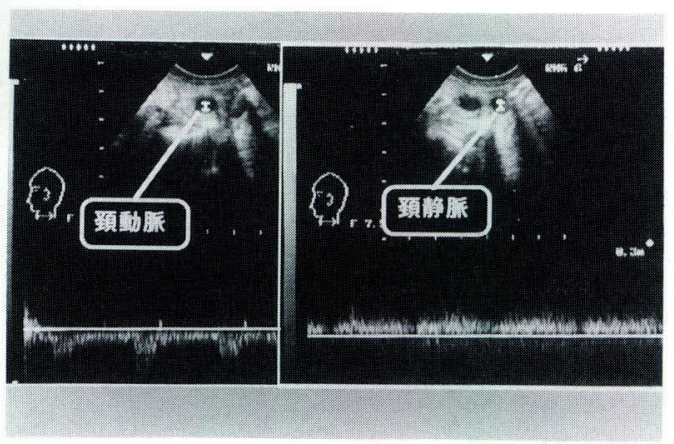

図 1

両頝部郭清を行った舌・ロ腔底腫瘍症例。保存的頝 部郭清側の血栓症のため両側とも䅡動脈しか描出さ れていない。

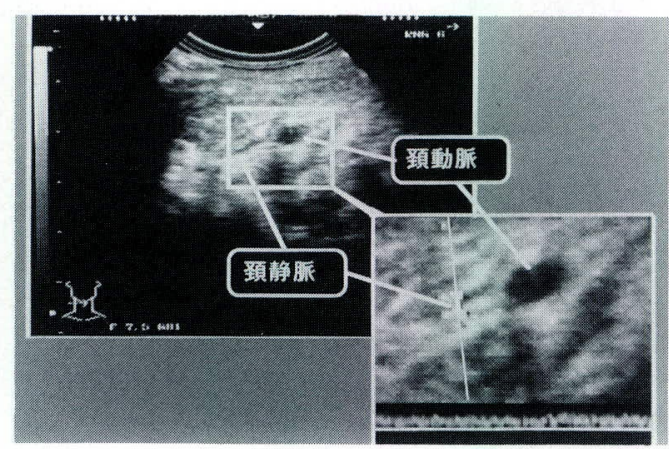

図 2

一側のみの保存的頝部郭清をおこなった中咽頭腫場 症例。内頝静脈が高度に狭窄しているが，ドップラ ーで血流が確認できる。

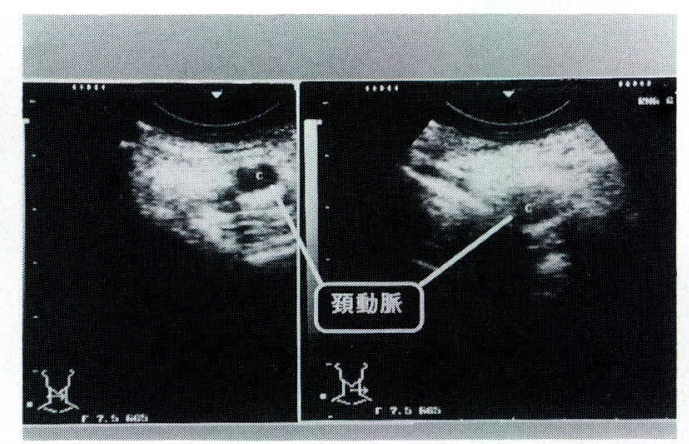

図 3

両側同時に頝部郭清をおこなった下咽頭腫瘍症例。 頝動脈・頸静脈が良く開存しており,ドップラーに て血流が確認できる。
表 2 内䅡静脈開存に関するこれまでの報告

\begin{tabular}{|c|c|c|c|c|}
\hline 年度 & 報告者 & 方 法 & 開存率 & 狭窄例 \\
\hline 1988 & Fisher" & C T & $85 \%(11 / 13)$ & 1 \\
\hline 1994 & Cotter ${ }^{5}$ & $\mathrm{C} T / \mathrm{MRI}$ & $94 \%(68 / 72)$ & 3 \\
\hline 1995 & Leontsinis ${ }^{3}$ & 血管造影 & $70 \%(19 / 27)$ & 不明 \\
\hline 1995 & Zohar ${ }^{6)}$ & エコー & $87 \%(27 / 31)$ & 2 \\
\hline 1996 & 著者ら & エコー & $96 \%(27 / 28)$ & 2 \\
\hline
\end{tabular}

表 3 内頝静脈狭窄例データ

\begin{tabular}{lllllll}
\hline 年度 & \multirow{2}{*}{$\begin{array}{l}\text { 報告者 } \\
\text { 狭窄例 }\end{array}$} & $\begin{array}{c}\text { 再建 } \\
\text { 放射線 } \\
\text { 治療(\%) }\end{array}$ & 合併症 & $\begin{array}{c}\text { 一側のみ } \\
\text { 保存郭清(\%) }\end{array}$ \\
\hline 1988 & Fisher $^{4)}$ & 1 & なし & 不明 & なし & 100 \\
1994 & Cotter $^{5)}$ & 3 & 不明 & 100 & 不明 & 33 \\
1995 & Leontsinis $^{3)}$ & 不明 & 不明 & 不明 & 不明 & 不明 \\
1995 & Zohar $^{6)}$ & 2 & なし & なし & なし & 100 \\
1996 & 著者ら $^{2}$ & 2 & 遊離 & 50 & 頝部瘻孔 & 100 \\
\hline
\end{tabular}

放射線治療、一側のみの保存郭清 (\%)は

各狭窄例中の何\%がそれぞれの治癔を受けた

かを示す。

れている。我々の唯一の内頝静脈閉塞例の原因を 検討してみると, 使用した有茎皮弁は RND 側 に用いており, 術中閉塞の原因となり得る血管損 傷を認めなかった。したがっで本症例では, 敗血 症・頝部膿瘍などの感染症, ショックによる血圧 低下などの術後合併症が静脈閉塞の原因である可 能性が高いと考えられた。

今回我々は内頝静脈狭窄を 2 例に認めた。狭窄 例についてはこれまでの報告でほとんど検討され ていないが, 内頝静脈狭窄の原因や将来の閉塞の 可能性など興味の持たれる点である。

自験例28例中内頝静脈狭窄を認めた 2 例に注目 すると, 表 1 の如く 2 例とも頝部郭清は一側のみ の FND であった。内頝静脈狭窄例の自験例お よび過去の報告 4 件のデー夕を, 文献に記載のあ る範囲でまとめると表 3 の如くなる。いずれの文 献も狭窄例についての記載が不十分なために確定 的なことは言いかねるが, 狭窄例は一側のみの FND に多い傾向が認められた。遊離皮弁が多用 され, 術後の QOL を考慮して FND が選択さ れる頻度が増加しつつある現状を考えると, 今後 注意を要するものと思われる。初回治療として一 側のみの FND を行い, 後に対側にリンパ節再 発を来した場合には特に問題となる。再発側の頝 部郭清にあたっては初回 FND 側の内頝静脈開 


\section{今手祐二 : 保存的䅡部郭清後の内頝静脈開存について}

存の有無を十分にチェックする必要があると思わ れた。FND 後の内頝静脈閉塞の原因の解明はも ちろんであるが, 狭窄例についても今後更に症例 数を増やし経時的に観察することが重要である。

\section{まとめ}

1. 保存的頝部郭清後の内頝静脈の開存を工 コーを用いて調べた。

2. 28例中 1 例に閉塞, 2 例に狭窄を認め, 内 顼静脈開存率は $96 \%$ であった。

3. 狭窄例は一側のみの保存的頝部郭清例に多 い傾向があった。

\section{文献}

1) Ahn C, Sindler WF : Bilateral radical neck dissection. Report of results in 55 patients. J
Surg Oncol. 40 : 252-255, 1989.

2) Marks SC, Jaques DA, Hirata RM, et al : Blindness following bilateral radical neck dissection. Head Neck. 12 : 342-345, 1990.

3) Leontsinis TG, Currie AR, Mannell A : Internal jugular vein thrombosis following functional neck dissection. Laryngoscope. 105 : 169-174, 1995

4) Fisher $C B$, Mattox D, Zinreich JS, et al : Patency of the internal jugular vein after funuctional neck dissection. Laryngoscope, 98 : 923-927, 1988

5) Cotter CS, Stringer SP, Landau $S$, et al : Patency of the internal jugular vein following modified radical neck dissection. Laryngoscope. 104: 841-84, 1994

6) Zohar $Y$, Strauss $M$, Sabo $R$, et al : Internal jugular vein patency after functional neck dissection. Venous duplex imaging. Ann Otol Rhinol Laryngol. 104 : 532-536, 1995 